ISSN 1678-3921

Journal homepage: www.embrapa.br/pab

For manuscript submission and journal contents, access: www.scielo.br/pab
Carlos André Stuepp ${ }^{(1 凶)}(\mathrm{D}$,

Fabiele Aparecida de Paula(2) (iD, Erika Cristina Cordeiro dos Santos(2) (D), Mônica Moreno Gabira(3) (D) and Ivar Wendling(4) (iD

(1) Universidade Estadual de Ponta Grossa, Departamento de Fitotecnia e Fitossanidade, Campus de Uvaranas, Avenida Carlos Cavalcanti, no 4.748, Bloco F, Uvaranas, CEP 84030-900 Ponta Grossa, PR, Brazil. E-mail: castuepp@uepg.br

(2) Universidade Estadual de Ponta Grossa, Departamento de Biologia Geral, Campus de Uvaranas, Avenida Carlos Cavalcanti, no 4.748, Bloco M, CEP 84030-900 Ponta Grossa, PR, Brazil. E-mail: fabieledepaula98@gmail.com, hakire1996@hotmail.com

(3) Universidade Federal do Paraná, Centro de Ciências Florestais e da Madeira, Campus Jardim Botânico, Avenida Prefeito Lothário Meissner, no 632, Jardim Botânico, CEP 80210-170 Curitiba, PR, Brazil. E-mail: monica.gabira@gmail.com

(4) Embrapa Florestas, Estrada da Ribeira, Km 111, Guaraituba, Caixa Postal 319, CEP 83411-000 Colombo, PR, Brazil. E-mail: ivar.wendling@embrapa.br

$\bowtie$ Corresponding author

Received

May 27, 2020

Accepted

November 26, 2020

How to cite

STUEPP, C.A.; PAULA, F.A. de; SANTOS, E.C.C. dos; GABIRA, M.M.; WENDLING, I. New technique for the early production of Araucaria angustifolia grafted plants. Pesquisa Agropecuária Brasileira, v.55, e02030, 2020. DOI: https://doi.org/10.1590/S1678-3921. pab2020.v55.02030.

\section{New technique for the early production of Araucaria angustifolia grafted plants}

\begin{abstract}
The objective of this work was to evaluate the grafting of Araucaria angustifolia in two container volumes and at three heights. Rootstocks with $30 \pm 5.0 \mathrm{~cm}$ were grafted with $4.0 \pm 1.0-\mathrm{cm}$ buds in 110 and $280-\mathrm{cm}^{3}$ plastic tubes (containers) at three heights $(5.0 \pm 1.0,10 \pm 1.0$, and $15 \pm 1.0 \mathrm{~cm})$. There was a reduction in graft survival as the height of the grafting point increased, and the lower volume limited the development of the root system. Therefore, grafting at $5.0 \pm 1.0 \mathrm{~cm}$ in $280-\mathrm{cm}^{3}$ containers brings new perspectives to improve the clonal forestry of the species, with a significant reduction in plants production time (of up to 12 months), as well as in production costs, used materials, and physical area.
\end{abstract}

Index terms: clonal forestry, clonal propagation, patch grafting, Paraná pine.

\section{Nova técnica para produção precoce de plantas enxertadas de Araucaria angustifolia}

Resumo - O objetivo deste trabalho foi avaliar a enxertia de Araucaria angustifolia em dois volumes de recipientes e três alturas. Porta-enxertos com $30 \pm 5,0 \mathrm{~cm}$ foram enxertados com borbulhas com 4,0 $\pm 1,0 \mathrm{~cm}$ em tubos de plástico (recipientes) de 110 e $280 \mathrm{~cm}^{3}$, em três alturas $(5,0 \pm 1,0,10 \pm 1,0$ e $15 \pm 1,0 \mathrm{~cm}$ ). Houve redução na sobrevivência dos enxertos com o aumento da altura de enxertia, e o menor volume limitou o desenvolvimento do sistema radicular. Portanto, a enxertia a $5,0 \pm 1,0 \mathrm{~cm}$ em recipientes de $280 \mathrm{~cm}^{3}$ traz novas perspectivas para o aprimoramento da silvicultura clonal da espécie, com redução significativa no tempo de produção de mudas (de até 12 meses), bem como nos custos de produção, nos materiais utilizados e na área física.

Termos para indexação: silvicultura clonal, propagação clonal, borbulhia de placa, pinheiro do Paraná.

Characteristic of mixed-forest landscapes in Southern Brazil, Araucaria angustifolia (Bertol.) Kuntze (Araucariaceae), popularly known as araucaria or Brazilian pine, is the only species of its genus that naturally occurs in the country (Wendling et al., 2017). Classified as an endangered species (Thomas, 2013), its overexploitation at the end of the nineteenth century had negative effects on its genetic variability, resulting in current restrictions on its use and exploitation (Hess et al., 2018).

Therefore, the production of $A$. angustifolia rootstocks has been one of the bottlenecks to implement the clonal propagation of this species through grafting, especially when aiming to produce seeds that are genetically improved or for food purposes (Stuepp et al., 
2018). Larger plants take longer to develop and occupy more space in the nursery, increasing costs (Chance et al., 2017), particularly for the formation of orchards for the production of A. angustifolia seeds (pine nuts). Therefore, defining new techniques to obtain vigorous $A$. angustifolia grafts is essential for the recommendation of this production system.

Despite the effectiveness of the grafting technique for $A$. angustifolia, the clonal forestry of this species is still a challenge (Constantino \& Zanette, 2015; Wendling et al., 2016; Rickli-Horst et al., 2019; Wendling, 2020). The rootstock production time of 12 to 24 months and the consequent high cost to produce grafted plants makes it harder to apply extensively this technique (Wendling et al., 2017). Grafting on smaller rootstocks is also complicated because of the morphological differences between rootstocks and grafts (buds from trunks or branches). A possible solution is the refinement of methods to achieve dimensional combinations (Rickli-Horst et al., 2019), with significant advances in the production of clonal propagules in clonal gardens in the field (Wendling et al., 2016; Rickli-Horst et al., 2019).

The objective of this work was to evaluate the grafting of Araucaria angustifolia in two volumes of containers and at three heights.

The experiments were carried out from December 2019 to April 2020 at the Forestry Nursery of Universidade Estadual de Ponta Grossa, located in the municipality of Ponta Grossa, in the state of Paraná, Brazil ( $25^{\circ} 05^{\prime} \mathrm{S}, 50^{\circ} 06^{\prime} \mathrm{W}$, at $912 \mathrm{~m}$ altitude). According to the Köppen-Geiger classification, the climate of the region is temperate, of the $\mathrm{Cfb}$ type, with the temperature of the coldest month between -3 and $18^{\circ} \mathrm{C}$, constant humidity, well-distributed rains throughout the year, and the temperature of the warmest month below $22^{\circ} \mathrm{C}$.

Plants of approximately 180 days were produced in containers with a capacity of 110 and $280 \mathrm{~cm}^{3}$ (Figure $1 \mathrm{~B})$; those with an average diameter of $0.5 \pm 0.2 \mathrm{~cm}$ and a height of $30 \pm 3.0 \mathrm{~cm}$ were selected as rootstocks for grafting. As an experimental control, rootstocks of around 18 months, produced in $3,780-\mathrm{cm}^{3}$ pots, were used (Wendling et al., 2017). The shoots of the trunk (orthotropic) with $5.0 \pm 3.0 \mathrm{~cm}$ in diameter were collected (Figure 1 A), packed in Styrofoam boxes with water and ice, and transported to carry out the experiment. Buds from shoots of the matrices established in a clonal garden in the field were used. The clonal garden, with five years of age, was implanted at a 2.0x1.0-m spacing and conducted under constant pruning and without specific nutrition. When around 35 years old, the matrices were originally selected in the field, rescued via grafting, and established in the clonal garden.

All rootstocks were cleaned in the grafting area, up to a height of $10 \pm 1.0 \mathrm{~cm}$ (Figure 1 B). Afterwards, the rootstocks were grafted in two container (conical plastic tubes) volumes and at three grafting heights, combined in the following treatments: $\mathrm{T} 1,110-\mathrm{cm}^{3}$ tubes with grafting at $5.0 \pm 1.0 \mathrm{~cm} ; \mathrm{T} 2,110-\mathrm{cm}^{3}$ tubes with grafting at $10 \pm 1.0 \mathrm{~cm}$; T3, $110-\mathrm{cm}^{3}$ tubes with grafting at $15 \pm 1.0 \mathrm{~cm} ; \mathrm{T} 4,280-\mathrm{cm}^{3}$ tubes with grafting at $5.0 \pm 1.0 \mathrm{~cm} ; \mathrm{T} 5,280-\mathrm{cm}^{3}$ tubes with grafting at $10 \pm 1.0$ $\mathrm{cm}$; and T6, 280- $\mathrm{cm}^{3}$ tubes with grafting at $15 \pm 1.0 \mathrm{~cm}$. $\mathrm{T} 7$, in $3,780-\mathrm{cm}^{3}$ pots with grafting at $50 \pm 10 \mathrm{~cm}$, was considered the control. The patch grafting technique was used, with buds of approximately $4.0 \pm 1.0 \mathrm{~cm}$ (Figure $1 \mathrm{C}$ ) adjusted to the rootstock contact surface (Figure $1 \mathrm{D}$ ). In all experiments, the tools and material used were: pruning shears to cut the plants, a pocket knife to prepare the graft and make the incision in the rootstocks, and a $2-\mathrm{cm}$ wide plastic tape to fix the grafts until they were welded (Figure $1 \mathrm{E}$ and F).

After the technique was applied, the grafted plants were placed in a shade house (50\% shade), under micro-sprinkler irrigation four times a day for $5 \mathrm{~min}$, at a flow rate of $144 \mathrm{~L}$ per hour, for a period of 120 days. The plastic tapes were removed after 45 days, and survival evaluations were performed at 60, 90, and 120 days after grafting. The experiment was installed in a completely randomized design, in a plot model subdivided over time, with four replicates of 10 grafts per experimental unit, totaling 280 grafts. The treatment variances were assessed for homogeneity by Bartlett's test, at 5\% probability, and the means of the variable survival, when significantly differing by the F-test, were compared by Tukey's test, at 5\% probability.

Graft survival showed a significant interaction between evaluation periods and treatments, influenced by the volume of the containers and grafting height. The containers with a volume of $280 \mathrm{~cm}^{3}$ were considered an alternative for $A$. angustifolia rootstock production. In fact, although rootstock thickness limited grafting conditions in $\mathrm{T} 4$, the treatment did not differ significantly from T7 (control). With the 
exception of T2 at 60 and 90 days and T3 in all periods, the other treatments were similar (Table 1).

Grafting at $5.0 \pm 1.0-\mathrm{cm}$ height was favorable for rootstocks in both containers, which is possibly associated with the greater lignification of the tissues in the stem basal portion of the plant. Grafting at lower heights, closer to the base, has led to good results for temperate fruit species (Das et al., 2018). In passion fruit (Passiflora gibertii N.E.Br.), for example, grafting height was effective in increasing vigor in nursery conditions (Lima et al., 2018). In the present study, a reduction in graft survival was observed as the height of the grafting point increased, which does not seem to be related to vascularity since the morphological patterns of the grafts in the 110 and $280-\mathrm{cm}^{3}$ containers were similar.

One hypotheses is that, in containers with a smaller volume, the spatial limitations may impair the performance of the root system, causing physiological stresses and hormonal responses, which culminate in the abscess of the graft. Several known reports have shown the importance of the rootstock root system in
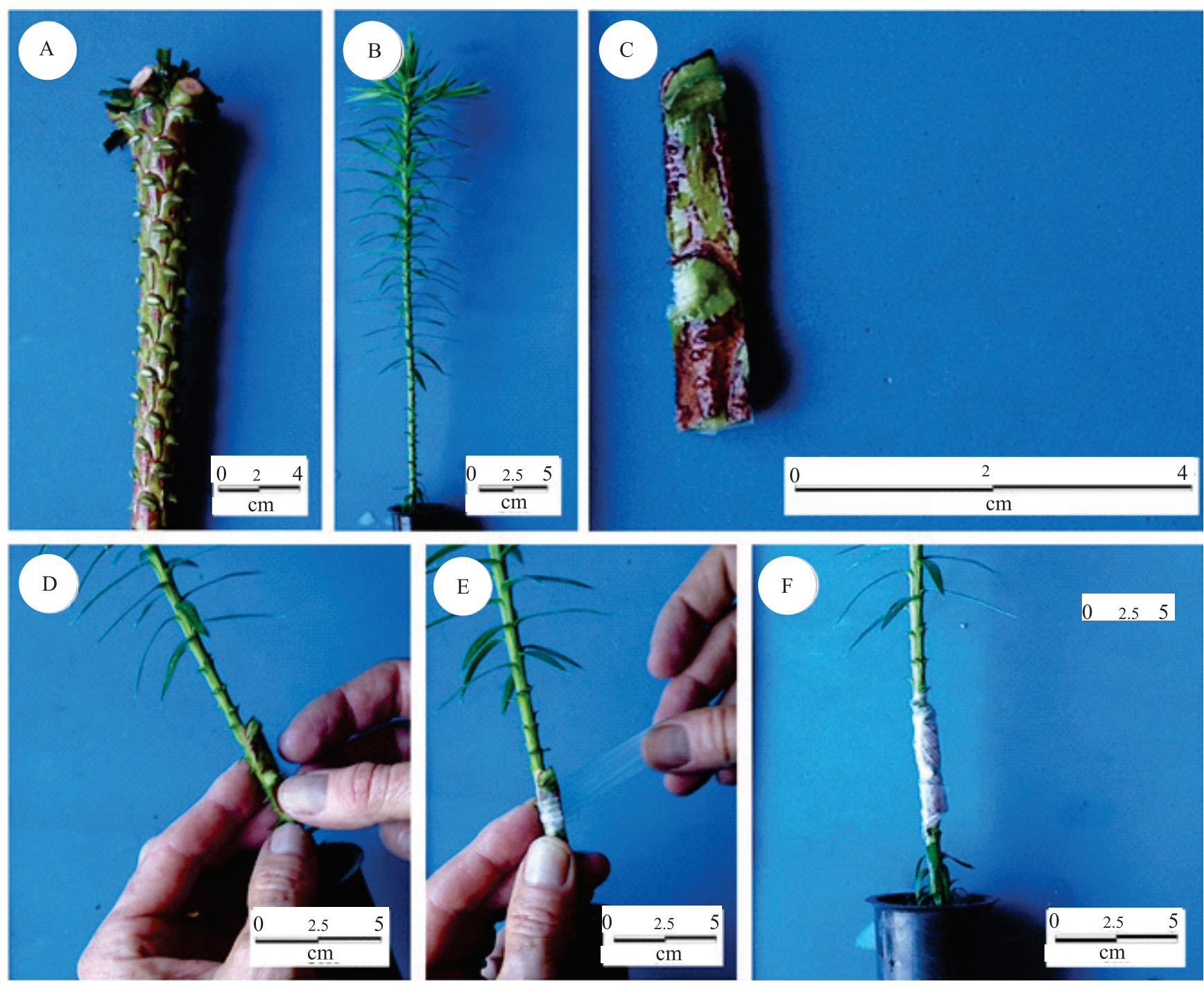

Figure 1. General characterization of the patch grafting technique applied to Araucaria angustifolia rootstocks, showing: A, shoot from a clonal garden in the field; B, rootstock with basal region cleaned for grafting; C, bud (patch) prepared from the shoot obtained from the clonal garden; D, grafting by adjusting the bud on the rootstock; E, fixation of the bud on the rootstock with a plastic tape; and E, graft ready, after the bud was sealed. 
Table 1. Survival of Araucaria angustifolia grafts at 60, 90, and 120 days after grafting in the municipality of Ponta Grossa, in the state of Paraná, Brazil ${ }^{(1)}$.

\begin{tabular}{lccccccc}
\hline Period (day) & $\mathrm{T} 1$ & $\mathrm{~T} 2$ & $\mathrm{~T} 3$ & $\mathrm{~T} 4$ & $\mathrm{~T} 5$ & $\mathrm{~T} 6$ & $\mathrm{~T} 7$ \\
\hline 60 & $70.0 \mathrm{aAB}$ & $45.0 \mathrm{aB}$ & $42.5 \mathrm{aB}$ & $80.0 \mathrm{aAB}$ & $65.0 \mathrm{aAB}$ & $52.5 \mathrm{aAB}$ & $85.0 \mathrm{aA}$ \\
90 & $65.0 \mathrm{aAB}$ & $37.5 \mathrm{aB}$ & $35.0 \mathrm{aB}$ & $77.5 \mathrm{aA}$ & $60.0 \mathrm{aAB}$ & $47.5 \mathrm{aAB}$ & $80.0 \mathrm{aA}$ \\
120 & $46.0 \mathrm{aAB}$ & $32.5 \mathrm{aAB}$ & $30.0 \mathrm{aB}$ & $65.0 \mathrm{aAB}$ & $50.0 \mathrm{aAB}$ & $40.0 \mathrm{aAB}$ & $70.0 \mathrm{aA}$ \\
\hline
\end{tabular}

Variation coefficient $(\%)=[$ Periods $=59.94][$ Treatments $=30.98]$

${ }^{(1)}$ Means followed by equal letters, uppercase in the rows and lowercase in the columns, do not differ by Tukey's test, at $5 \%$ probability. T1, 110 -cm ${ }^{3}$ tubes with grafting at $5.0 \pm 1.0 \mathrm{~cm} ; \mathrm{T} 2,110-\mathrm{cm}^{3}$ tubes with grafting at $10 \pm 1.0 \mathrm{~cm} ; \mathrm{T} 3,110-\mathrm{cm}^{3}$ tubes with grafting at $15 \pm 1.0 \mathrm{~cm} ; \mathrm{T} 4,280-\mathrm{cm}^{3}$ tubes with

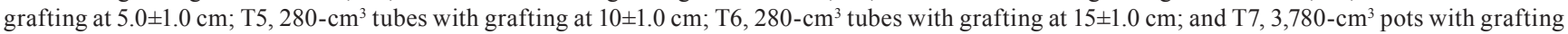
at $50 \pm 10 \mathrm{~cm}$ (control).

the nutrition and adequate development of vegetables (Lima et al., 2018; Barrios-Masias et al., 2019).

Furthermore, the different dimensions between rootstocks and grafts (Figure 1) may reflect a poor vascular connection between both of them. This variation can cause limitations related to welding, since there is not a proper contact between the two plant portions, which, in this case, may lead to the oxidation of the non-overlapping parts of the bud (Rickli-Horst et al., 2019). As this is the first experimental application of the budding technique on smaller and newer rootstocks, variations and even higher percentages of propagule mortality were expected. However, these variations tend to be normalized as the technique is refined, with a better adjustment of the rootstocks, especially regarding stem lignification, which makes it easier for the operator to properly fix the bud on the rootstock.

The results obtained in the present study reinforce the limitations caused by the rootstocks produced in containers with smaller volumes, both in the application of the grafting technique and in the conduction of grafts after grafting. Therefore, the development of the root system is limited in containers with a volume of 110 $\mathrm{cm}^{3}$, reflecting a higher rate of graft mortality in the first evaluation at 60 days after grafting (Table 1). This happens because root system architecture depends on the dynamics of root development, in response mainly to the environment, seeking to absorb resources for the best possible performance (Judd et al., 2015). When the environment is physically limited, the tendency is to generate a root system with a smaller surface area, and, therefore, a lower capacity for nutrient absorption and translocation of resources.
Considering these limitations, the possibility of producing A. angustifolia plants in $280-\mathrm{cm}^{3}$ containers with grafting at $5.0 \pm 1.0 \mathrm{~cm}$ height brings new perspectives to improve the clonal forestry of the species, with a significant reduction in plants production time (of up to 12 months), as well as in production costs, used materials, and physical area. This grafting technique showed a similar efficiency to that of traditional clonal propagation through grafting, represented by $\mathrm{T} 7$ (control).

The grafting technique has several other positive points. When taken to the field, for example, plants produced in smaller containers and that are, consequently, newer tend to suffer less from the generated stresses, which enables a greater growth force according to the characteristics of the grafted propagules (Gilman et al., 2013). In addition, there is a greater availability of containers with smaller volumes on the market and with quality to guarantee the proper development of the root system, avoiding problems such as root folding (Amoroso et al., 2010; Gilman et al., 2013).

\section{References}

AMOroso, G.; FRANGI, P.; PIATTI, R.; FERRINI, F.; FINI, A.; FAORO, M. Effect of container design on plant growth and root deformation of littleleaf linden and field elm. HortScience, v.45, p.1824-1829, 2010. DOI: https://doi.org/10.21273/ HORTSCI.45.12.1824.

BARRIOS-MASIAS, F.H.; KNIPFER, T.; WALKER, M.A.; MCELRONE, A.J. Differences in hydraulic traits of grapevine rootstocks are not conferred to a common Vitis vinifera scion. Functional Plant Biology, v.46, p.228-235, 2019. DOI: https://doi.org/10.1071/FP18110. 
CHANCE, L.M.G.; ARNOLD, M.A.; LOMBARDINI, L.; WATSON, W.T.; CARVER, S.T.; KING, A.R. Landscape establishment for baldcypress, red maple, and chaste tree is delayed for trees transplanted from larger containers. Journal of Environmental Horticulture, v.35, p.43-57, 2017. DOI: https://doi.org/10.24266/0738-2898-35.2.43.

CONSTANTINO, V.; ZANETTE, F. Produção de borbulhas ortotrópicas para enxertia de Araucaria angustifolia. Acta Biológica Paranaense, v.44, p.49-55, 2015. DOI: https://doi.org/10.5380/abpr.v44i1-4.47598.

DAS, B.; KISHOR, A.; AHMED, N. Budding and grafting time and height as determining factors for bud take and successive plant growth in some temperate fruits. Indian Journal of Horticulture, v.75, p.326-331, 2018. DOI: https://doi.org/10.5958/09740112.2018.00055.5.

GILMAN, E.F.; MIESBAUER, J.; HARCHICK, C.; BEESON, R.C. Impact of tree size and container volume at planting, mulch, and irrigation on Acer rubrum L. growth and anchorage. Arboriculture \& Urban Forestry, v.39, p.173-181, 2013.

HESS, A.F.; LOIOLA, T.; SOUZA, I. de S.; MINATTI, M.; RICKEN, P.; BORSOI, G.A. Forest management for the conservation of Araucaria angustifolia in southern Brazil. Floresta, v.48, p.373-382, 2018. DOI: https://doi.org/10.5380/ rf.v48i3.55452.

JUDD, L.A.; JACKSON, B.E.; FONTENO, W.C. Advancements in root growth measurement technologies and observation capabilities for container-grown plants. Plants, v.4, p.369-392, 2015. DOI: https://doi.org/10.3390/plants4030369.

LIMA, L.K.S.; SANTOS, I.S. dos; GONÇALVES, Z.S.; SOARES, T.L.; JESUS, O.N. de; GIRARDI, E.A. Grafting height does not affect Fusarium wilt control or horticultural performance of Passiflora gibertii N.E.Br. rootstock. Anais da
Academia Brasileira de Ciências, v.90, p.3525-3539, 2018. DOI: https://doi.org/10.1590/0001-3765201820180072.

RICKLI-HORST, H.C.; WENDLING, I.; KOEHLER, H.S.; ZUFFELLATO-RIBAS, K.C. Araucaria angustifolia budding techniques in indoor and outdoor stablished rootstocks. Floresta e Ambiente, v.26, e20170799, 2019. DOI: https://doi.org/10.1590/2179-8087.079917.

STUEPP, C.A.; WENDLING, I.; XAVIER, A.; ZUFFELLATORIBAS, K.C. Vegetative propagation and application of clonal forestry in Brazilian native tree species. Pesquisa Agropecuária Brasileira, v.53, p.985-1002, 2018. DOI: https://doi.org/10.1590/ S0100-204X2018000900002.

THOMAS, P. Araucaria angustifolia. The IUCN red list of threatened species, e.T32975A2829141, 2013. DOI: https://doi. org/10.2305/IUCN.UK.2013-1.RLTS.T32975A2829141.en.

WENDLING, I. BRS 405, BRS 406 e BRS 407: cultivares clonais femininas de araucária para produção de pinhão. Colombo: Embrapa Florestas, 2020. 7p. (Embrapa Florestas. Comunicado técnico, 443).

WENDLING, I.; STUEPP, C.A.; ZUFFELLATO-RIBAS, K.C. Araucaria clonal forestry: types of cuttings and mother tree sex in field survival and growth. Cerne, v.22, p.19-26, 2016. DOI: https://doi.org/10.1590/01047760201622012105.

WENDLING, I.; ZANETTE, F.; RICKLI-HORST, H.C.; CONSTANTINO, V. Produção de mudas de araucária por enxertia. In: WENDLING, I.; ZANETE, F. (Ed.). Araucária: particularidades, propagação e manejo de plantios. Brasília: Embrapa, 2017. p.107-144. 